\title{
Islamic Arts and Crafts
}

An Anthology

Marcus Milwright 
Edinburgh University Press is one of the leading university presses in the UK. We publish academic books and journals in our selected subject areas across the humanities and social sciences, combining cutting-edge scholarship with high editorial and production values to produce academic works of lasting importance. For more information visit our website: edinburghuniversitypress.com

Selection and editorial material (C) Marcus Milwright, 2017

The texts are reprinted by permission of other publishers

Edinburgh University Press Ltd

The Tun - Holyrood Road

12 (2f) Jackson's Entry

Edinburgh EH8 8PJ

Typeset in 10/12pt JaghbUni by

Servis Filmsetting Ltd, Stockport, Cheshire,

printed and bound in Great Britain by

CPI Group (UK) Ltd, Croydon CR0 4YY

A CIP record for this book is available from the British Library

ISBN 9781474409162 (hardback)

ISBN 9781474409193 (paperback)

ISBN 9781474409179 (webready PDF)

ISBN 9781474409186 (epub)

The right of Marcus Milwright to be identified as author of this work has been asserted in accordance with the Copyright, Designs and Patents Act 1988 and the Copyright and Related Rights Regulations 2003 (SI No. 2498).

Published with the support of the University of Edinburgh Scholarly Publishing Initiatives Fund. 